\title{
Livestock Herbivory Shapes Fire Regimes and Vegetation Structure Across the Global Tropics
}

\author{
Rafael E. Bernardi, ${ }^{1,2,3 *} \odot$ Arie Staal, ${ }^{2} \odot$ Chi Xu, ${ }^{4} \odot$ Marten Scheffer, ${ }^{2}$ and \\ Milena Holmgren ${ }^{1}$
}

\begin{abstract}
${ }^{1}$ Resource Ecology Group, Wageningen University, Droevendaalsesteeg 3a, 6708 PB Wageningen, The Netherlands; ${ }^{2}$ Aquatic Ecology and Water Quality Management Group, Wageningen University, Droevendaalsesteeg 3a, 6708 PB Wageningen, The Netherlands;

${ }^{3}$ Departamento de Ecología y Gestión Ambiental, Centro, Universitario Regional Este (CURE), Universidad de la República, Maldonado, Uruguay; ${ }^{4}$ School of Life Sciences, Nanjing University, 163 Xianlin Road, Nanjing 210023, China
\end{abstract}

\begin{abstract}
Livestock grazing is the most extensive human land use and one of the key drivers of the conversion of tropical forests into grasslands. Livestock effects on vegetation structure are complex, as they can prevent tree recruitment and growth through browsing and trampling, but they can also affect vegetation indirectly through fire interactions. However, a systematic analysis of the overall effects of livestock across the global tropics is lacking. We analyzed remote sensing data on vegetation height and cover, climate, and fire as well as ground data on livestock density. We used generalized linear models and structural equation models to analyze the effects of livestock on fire regimes and vegetation structure. Across the global tropics, higher livestock densities are associated to lower fire frequency and a higher cover of shrubs and dwarf trees. This pattern occurs across continents, and is particularly pronounced at intermediate precipita-
\end{abstract}

tion levels (1000-1500 $\mathrm{mm} \mathrm{y}^{-1}$ ) where fire frequency is highest. In those regions, fire frequency is on average $49 \%$ lower in areas with high versus low livestock densities. South America has much higher livestock density and lower fire frequency than Africa and Asia-Australia across the whole precipitation gradient. Our findings suggest that livestock grazing reduces fire incidence through grass consumption and favors shrubs and a sparse cover of trees in regions where forests could potentially exist. Livestock can thus be a strong modifier of the climatic effect on vegetation structure, and livestock management changes can impact the structure and functioning of savannas and grasslands throughout the global tropics.

Key words: Africa; Australia; savannas; shrub encroachment; South America; subtropical; tree cover; woody plants.
Electronic supplementary material: The online version of this article (https://doi.org/10.1007/s10021-019-00349-x) contains supplementary material, which is available to authorized users.

Authors' Contributions RB conceived the original idea. All authors designed the methodology. RB and CX processed the data. All authors interpreted the results, $\mathrm{RB}$ and $\mathrm{MH}$ led the writing and all authors contributed to revising the manuscript.

*Corresponding author; e-mail: bernardirafael@gmail.com

\section{HighLIGHTS}

- We analyze livestock effects on fire and vegetation patterns in the global tropics.

- Fire frequency is negatively correlated with livestock across the tropics.

- Livestock favors shrubs and low tree cover in areas which could support forests. 


\section{INTRODUCTION}

Livestock grazes approximately one-third of the global land surface and about half of the world's savannas and grasslands. In the tropics, livestock ranching extends over 32 million $\mathrm{km}^{2}$, twice the area covered by tropical moist forest (Asner and others 2004; Thornton and Herrero 2010). Despite this enormous extent, the effects of livestock management on vegetation structure have never been assessed globally. Livestock effects are hotly debated because regional- and site-level studies have described both increases and decreases in woody cover expansion with contrasting consequences for the long-term provision of ecosystem services. Grazing can promote woody encroachment (Scholes and Archer 1997; Roques and others 2001; Eldridge and others 2011) by shifting competitive interactions between herbaceous and woody plants in favor of the latter (Walter 1939; Knoop and Walker 1985; Belsky and Blumenthal 1997) or by reducing grasses that fuel fires (Bond 2008; Stevens and others 2017). On the other hand, livestock can limit woody expansion through direct browsing and trampling on tree seedlings and saplings (Huntly 1991; Prins and van der Jeugd 1993; Griscom and others 2005; Holmgren and others 2006; Chaturvedi and others 2012; Staver and Bond 2014; Bernardi and others 2016b; Etchebarne and Brazeiro 2016). Browsing can also affect tree growth by causing apical damage and activating lateral buds, which results in dwarf trees with a bushy architecture (Huntly 1991; Bond and Midgley 2001; Holmgren 2002; Archibald and Bond 2003).

The effects of grazing on fire dynamics may be particularly important for shaping the structure and functioning of tropical and subtropical terrestrial ecosystems. Fire may maintain open grasslands and savannas because trees are more susceptible than grasses to fire events. Grasses regrow fast after fire and thereby provide fuel for a subsequent fire. This creates a grass-fire positive feedback that maintains sparse tree cover. As a result of such a strong firefiltering process, savanna ecosystems are dominated by fire-resistant woody species with traits well adapted to frequent fires (Archibald and others 2009; Hoffmann and others 2012). The grass-fire feedback has been proposed as the main mechanism explaining bimodal patterns in tropical tree cover (Hirota and others 2011; Staver and others 2011; van Nes and others 2018) and canopy height (Xu and others 2016; $\mathrm{Xu}$ and others 2018) in the $1000-2000 \mathrm{~mm} \mathrm{y}^{-1}$ precipitation range. This implies that tropical forest and savanna can be alter- native stable states separated by tipping points (Scheffer and others 2009; Hirota and others 2011). By consuming grass biomass, livestock grazing can mediate this fire feedback, thereby shaping vegetation structure in an indirect way. This effect, together with the limitation of tree recruitment and growth, could potentially lead to large-scale effects on vegetation distribution and structure.

Given the widespread presence of livestock and their potential effects on fire regimes and vegetation, here we assess the interactions between livestock density, fire occurrence, and vegetation structure across the global tropics.

\section{MeThodS}

\section{Global Databases}

Our study region is the global tropics and subtropics between $15^{\circ} \mathrm{N}$ and $35^{\circ} \mathrm{S}$, a region selected for consistency with previous works (Hirota and others 2011; Staal and others 2016; Xu and others 2016; van Nes and others 2018) (Figure 1). We generated a $0.1^{\circ} \times 0.1^{\circ}$ fishnet with approximately 500,000 grid cells covering the study region. For each grid cell, we collected estimates of livestock density, fire frequency, tree cover, shrub cover, mean annual precipitation, and precipitation seasonality. Livestock density was obtained from the FAO Gridded Livestock of the World modeled dataset at $1 \mathrm{~km}$ resolution (Robinson and others 2014) and expressed in 250-kg-equivalent animal units called Tropical Livestock Units (TLU) using a scale of 0.7 for cattle, 0.5 for buffaloes and 0.1 for goats and sheep (FAO 1999). To avoid pseudoreplication of nested environmental variables that are included in the FAO model, we averaged the model values for each administrative division following Bernardi and others (2016b). We differentiated between high and low livestock densities, defined as being above and below the pantropical average value of TLU (7 TLU $\mathrm{km}^{-2}$ ). This value is equivalent to $1750 \mathrm{~kg} \mathrm{~km}^{-2}$ which is very similar to the value $\left(1500 \mathrm{~kg} \mathrm{~km}^{-2}\right.$ ) around which fire frequency in Africa decreases rapidly (Archibald and Hempson 2016). We performed our analysis for different precipitation ranges.

Fire frequency was derived by calculating burned frequency (burns per year) from the standard MODIS burned area product MCD45 (Roy and others 2008) for the years 2002-2010. We considered the start of each year in April and the end in March the next year, coinciding with the annual global minimum fire activity during March-April (Giglio and others 2013), to generate annual composite burned area maps. 


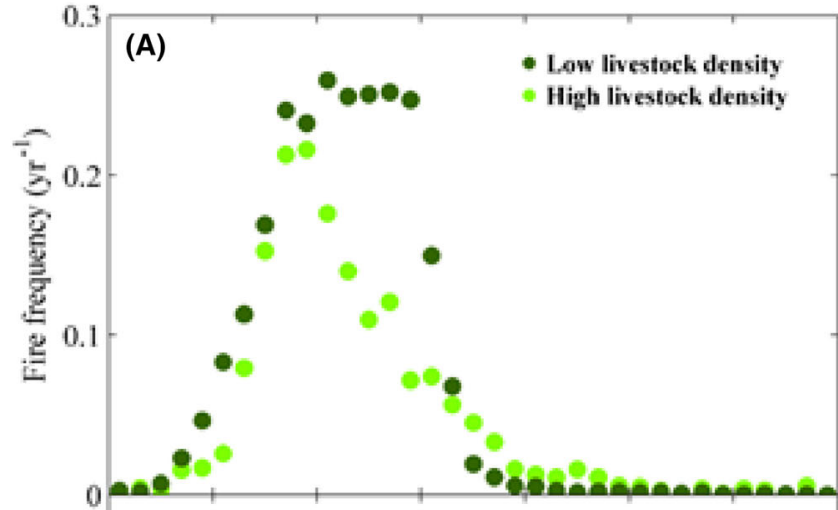

(B)

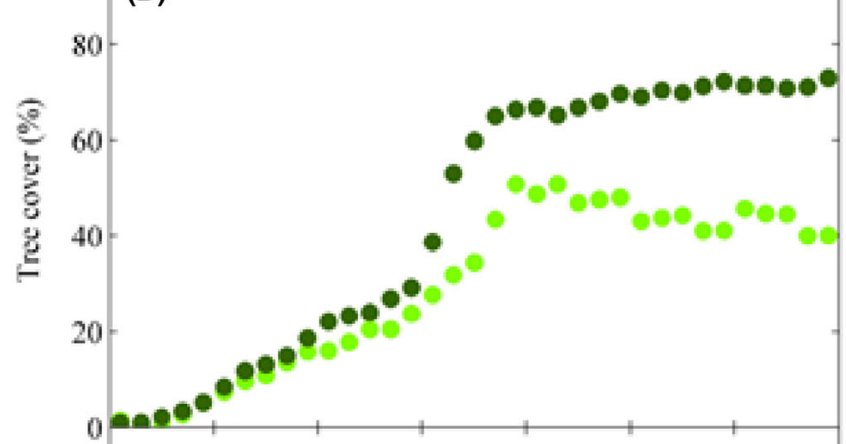

(C)

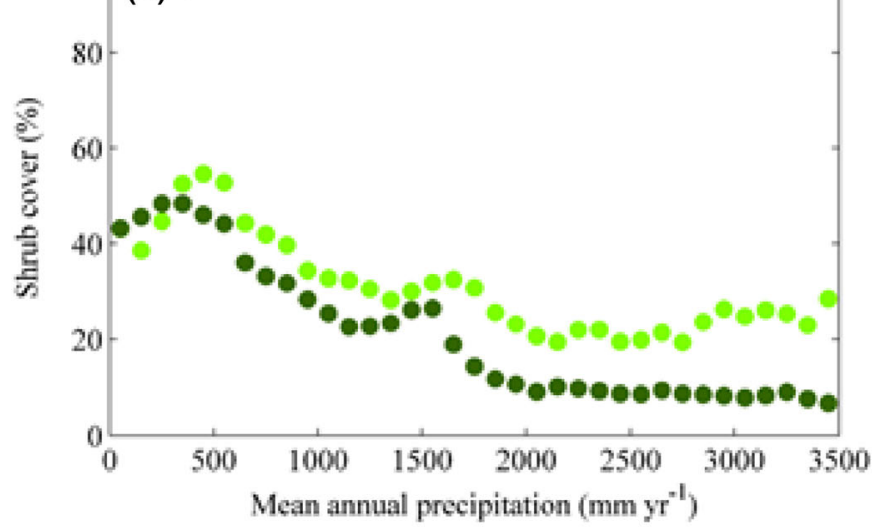

(D)

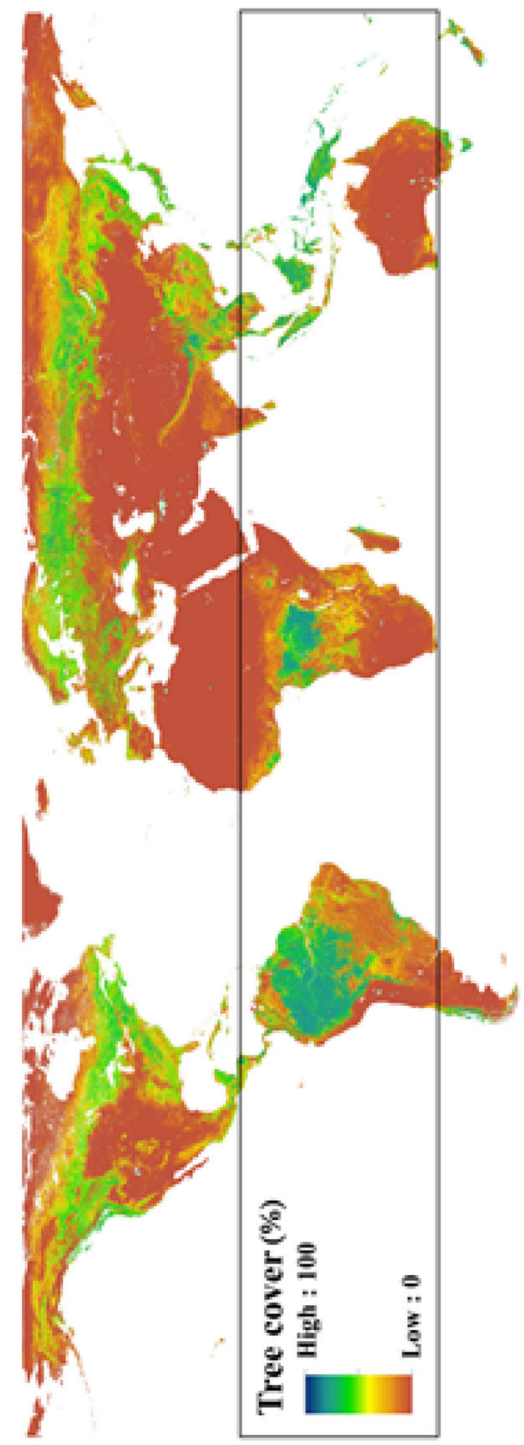

Figure 1. Differences in fire frequency, tree cover and shrub cover associated with tropical livestock density. A Mean fire frequency averaged in $100 \mathrm{~mm}$ mean annual precipitation bins for sites with above-average (TLU $\geq 7 \mathrm{units} \mathrm{km}^{-2}$, light dots) versus below-average (TLU $<7$ units $\mathrm{km}^{-2}$, dark dots) livestock densities, B tree cover (\%), C cover of shrubs and dwarf trees $(\%)$, D region of analysis.

Tree cover data were extracted from the MODIS Vegetation Continuous Field (VCF) Collection 5 dataset for the year 2009 (DiMiceli and others 2011). The MODIS VCF product estimates tree cover as the woody cover taller than $5 \mathrm{~m}$. To estimate woody cover below this $5 \mathrm{~m}$ lower limit (including dwarf trees and shrubs, hereafter referred to as shrub cover for simplification), we used a remote sensing dataset (LiDAR) of global vegetation height (Los and others 2012). The $5 \mathrm{~m}$ threshold between trees and shrubs coincides with standard life forms definitions (Pérez-Harguindeguy and others 2016) and is supported by observed distributions of global vegetation height for trees and shrubs (Scheffer and others 2014; Xu and others 2016). The LiDAR dataset of vegetation height was assembled using measurements ("footprints") collected by the Geoscience Laser Altimeter System (GLAS) on the Ice, Cloud and land Elevation Satellite (ICESat) during the years 20032009. It gives the vegetation height distribution between $0-70 \mathrm{~m}$ in $0.5 \mathrm{~m}$ intervals per $0.5^{\circ} \times 0.5^{\circ}$ 
grid cell. The shrub cover was calculated as the percent of LiDAR footprints falling in the 1-5 m range over the total footprints for each cell. We tested for the robustness of our estimates using a different canopy height range $(0.5-1.5 \mathrm{~m}$ for the lower height) to define dwarf trees and shrubs, but this did not yield significantly different results.

Climate data were obtained from the Climate Research Unit (CRU) database at $0.5^{\circ}$ resolution for the period 1951-2002 (Jones and Harris 2013), from which we derived mean annual precipitation (MAP) and precipitation seasonality. As measure of seasonality, we used Markham's Seasonality Index (MSI) (Markham 1970).

We excluded from all datasets the areas covered by croplands, water or bare ground, as defined as categories [11-30 and 190-230] in the 2009 European Space Agency (ESA) Globcover dataset at $300 \mathrm{~m}$ resolution. Analyses were performed using ArcGIS 10.0 and R 3.2.3.

\section{Data Analyses}

We used Generalized Linear Models (GLM) to correlate fire frequency (number of burns), tree cover and shrub cover (\%) with explanatory variables. Explanatory variables were mean annual precipitation (MAP), Markham's Seasonality Index (MSI), fire frequency $(F)$ and livestock density (LD). The analysis included the whole tropics and subtropics between $15^{\circ} \mathrm{N}$ and $35^{\circ} \mathrm{S}$. We used a Poisson distribution for fire frequency and used ordinary least square models for the tree and shrub cover models. We applied an arcsine-square root transformation for tree cover, following Hirota and others (2011). Variables were scaled. We used a random subsample of $1 \%$ of the points and selected the best models with the bestglm function based on the Akaike Information Criterion (AIC). Spatial autocorrelation in the model residuals was assessed using Moran's I. We found weak spatial autocorrelation indicated by rather low Moran's I values (Table S1 in Supporting Information). We also detected weak multicollinearity among the explanatory variables (Pearson's $\rho<0.45$ in all cases). The statistical analyses were performed in R 3.2.3 with the packages bestglm (McLeod and Xu 2011) and geoR (Ribeiro Jr and Diggle 2001).

To facilitate a comprehensive understanding on how the focal factors interact with each other, we developed a conceptual model based on the observed relationships between variables for the whole area of study area. We constructed a piecewise structural equation model (SEM) to test this network of relationships using the piecewiseSEM package (Lefcheck 2016) in R 3.2.3. Although there may be complex causal relationships among livestock, fire, and vegetation, the SEM allows us to propose a "minimal model" (van Nes and Scheffer 2005) and to statistically test for predicted relationships between the main variables. We performed bootstrapping with 1000 repetitions, using randomly selected 1000 points per run. The observed relationships based on bootstrapping are highly consistent with those based on all data points, indicating that our results are not biased by the repeated sampling of coarse-grained data.

\section{RESUltS}

Across the tropics, high livestock density correlates with lower fire frequency $(p<0.001$; Table S1). Fire frequency is highest at intermediate precipitation levels (Figure 1A). However, at which level it peaks depends on livestock density. At low livestock density, fire frequency remains high up to $1500 \mathrm{~mm}$ annual precipitation whereas at high livestock density, fire frequency declines sharply after $1000 \mathrm{~mm} \mathrm{y}^{-1}$. Within this $1000-1500 \mathrm{~mm} \mathrm{y}^{-1}$ range, fire frequency is on average $49 \%$ lower at high livestock density. We also find differences in vegetation structure between sites with low and high livestock densities. High livestock density correlates with lower tree cover (Figure 1B; $p<0.001$ ) and higher shrub cover (Figure 1C; $p<0.001$ ), especially at precipitation levels above $1500 \mathrm{~mm} \mathrm{y}^{-1}$.

We synthesized these relationships among livestock density, fire frequency and vegetation structure into a conceptual model (Figure 2) and assessed them using structural equation models (SEMs). We found that livestock has significant negative effects on fire frequency and tree cover $(p<0.001)$, and an indirect positive effect on shrub cover through suppressing tree cover (Figure 3). Based on the patterns reflected in Figure 1, we also developed SEMs for three different subsets of mean annual precipitation (MAP): dry areas (MAP $<1000 \mathrm{~mm} \mathrm{y}^{-1}$ ), intermediate precipitation areas $\left(1000 \leq \mathrm{MAP}<1500 \mathrm{~mm} \mathrm{y}^{-1}\right)$ and wet areas (MAP $\geq 1500 \mathrm{~mm} \mathrm{y}^{-1}$ ). We found that the negative effects of livestock on fire only become significant above $1000 \mathrm{~mm} \mathrm{y}^{-1}$ precipitation (Figure S1).

South America has much higher livestock density and lower fire frequency than Africa and AsiaAustralia across the whole precipitation gradient (Figure 4). Despite these differences in magnitude, we find that fire frequency peaks between 1000- 
$1500 \mathrm{~mm} \mathrm{y}^{-1}$ of precipitation across all continents (Figure 4). This is also the precipitation range where the effect of livestock on fire is largest for all continents. As done for the global tropics, we developed SEMs for each continent at the same three levels of MAP (Figure S2). In Africa, livestock has a negative effect on fire across climates, whereas in Asia-Australia this is the case only at intermediate and high precipitation, and in South America only at intermediate precipitation (Figure S8). Curiously, the effect of livestock on fire turns weakly positive in the wet regions of South America.

\section{Discussion}

Our results suggest that livestock reduces fire frequency across the global tropics (Figures 1, 3; Table S1). This is in line with local and regional studies showing that grazing limits fire occurrence by either reducing the availability of grass fuel (Bond 2008), or by forming grazing lawns that act as barriers for fire spread (Leonard and others 2010; Hempson and others 2015b).

Sites with higher livestock densities have sparser tree cover (Figures 1B, S3) but a denser cover of low-statured woody plants (dwarf trees and shrubs) (Figures 1C, S4). This is likely the net result of conflicting effects of livestock on trees and shrubs. Livestock includes grazers and mixed feeders that differ in foraging behavior and preferences for herbaceous and woody plants (Shipley 1999). On the one hand, regenerating trees and shrubs may benefit from fire suppression in grazed lands,

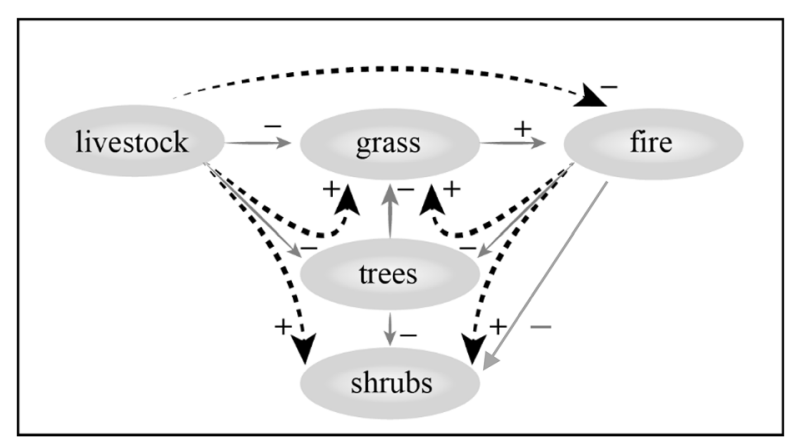

Figure 2. Conceptual model of the relationships between livestock, grass cover, fire frequency and tree and shrub cover. Positive effects are indicated by pluses and negative effects by minuses; dashed lines indicate indirect effects. Livestock grazing reduces grass cover and thereby fuel for fire, favoring woody expansion; however, livestock grazing also limits tree growth, favoring shrubs and dwarf trees which are highly susceptible to fire.

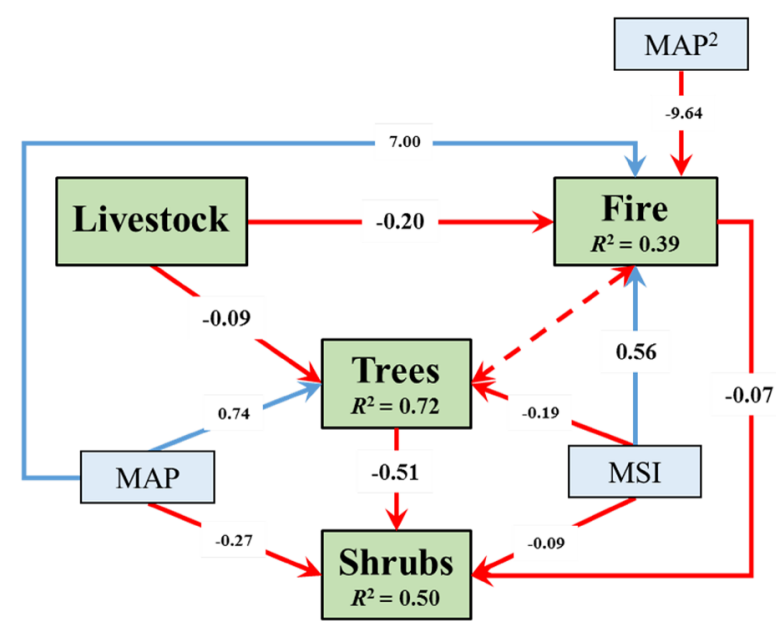

Figure 3. Piecewise structural equation model. Positive relations in blue arrows, negative in red. Dashed arrows indicate a strong mutual effect. All tested relationships have $p$ values $<0.001$. Numbers indicate coefficient estimates of relationships. The light-blue boxes indicate climatic variables (MAP, mean annual precipitation; MAP $^{2}$, quadratic term of MAP; MSI, Markham's Precipitation Seasonality Index), the green boxes represent ecosystem variables (Livestock, livestock density; Fire, fire frequency; Trees, tree cover; Shrubs, cover of shrubs and dwarf trees). $R^{2} \mathrm{~s}$ for component models are shown in the boxes of response variables. The Fire model is fitted using generalized linear model with Poisson distribution, the Trees and Shrubs models are fitted using ordinary least square models (Color figure online).

especially when grazers control grass growth (Belsky and Blumenthal 1997; Scholes and Archer 1997; Roques and others 2001; Asner and others 2009; D'Odorico and others 2012). On the other hand, by browsing and trampling on young seedlings and saplings, livestock can also limit tree recruitment, resulting in a reduction in tree cover after a few decades of foraging. Also, browsing at early growth stages can favor multi-stemmed, shorter-sprouted trees which can contribute to the increased shrub cover detection in areas with high livestock density. Cultural views of livestock managers can also contribute to removing regenerating trees (Holmgren and Scheffer 2017) despite their potential positive effects on forage productivity (Bernardi and others 2016a). Therefore, trees need time and favorable growth conditions to escape from the control imposed by herbivory and people (Holmgren and others 2006; Bond 2008; Scheffer and others 2008; Hoffmann and others 2012).

The apparent effects of livestock on fire and vegetation structure have important implications for our interpretation of the biogeographic distri- 

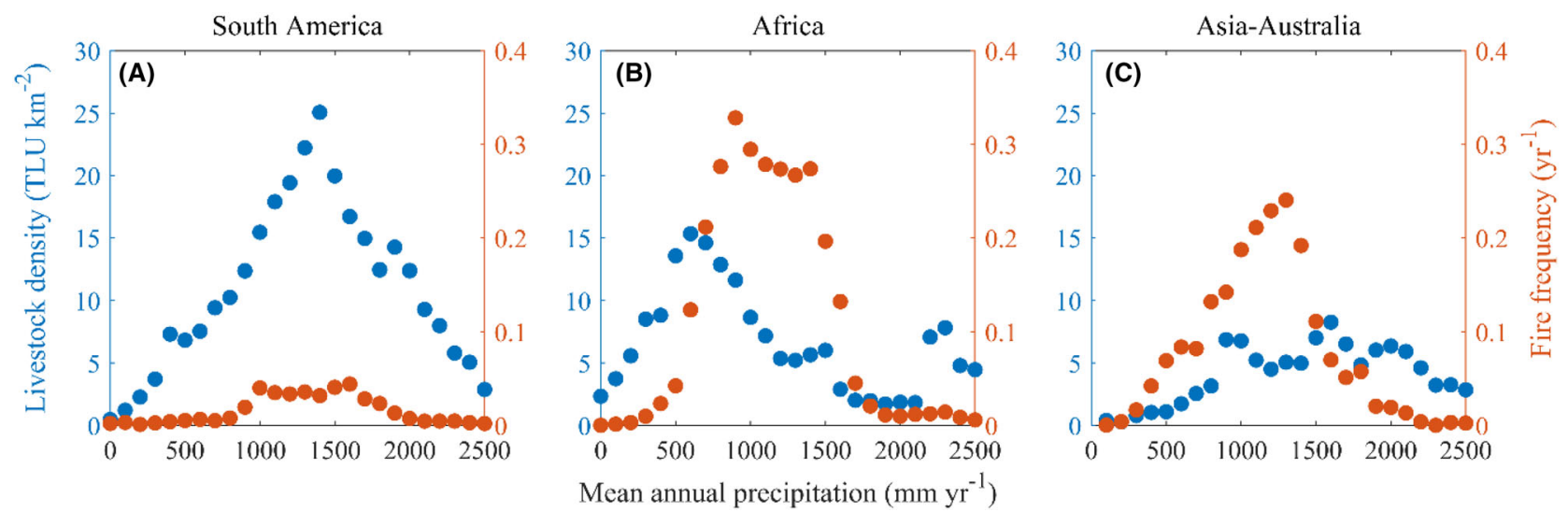

Figure 4. Livestock density (blue circles) and fire frequency (brown circles) as a function of precipitation for A South America, B Africa, and C Australia. Values averaged over $100 \mathrm{~mm}$ bins of mean annual precipitation (Color figure online).

butions of forests and savannas. Remote sensing studies suggest that savannas and forests can be alternative stable states (Hirota and others 2011; Xu and others 2016), maintained by a grass-fire feedback (Staver and others 2011; Hoffmann and others 2012; Murphy and Bowman 2012; van Nes and others 2018). Also, local- and regional-scale studies using empirical (Archibald and others 2005; Archibald and Hempson 2016; Dantas and others 2016) and modeling approaches (van Langevelde and others 2003; Suding and others 2004; Staal and others 2018) indicate that herbivory can replace fire as main disturbance generating alternative tree cover states. Our analysis shows that livestock can control tree recruitment despite the reduction in fire frequency. In these regions, livestock likely promotes sparse woody vegetation with a shrubby architecture that can persist in the absence of fire.

The reduction of fire frequency at higher livestock densities becomes significant across the tropics above $1000 \mathrm{~mm}$ of mean annual precipitation, as productivity increases. It is particularly significant at intermediate precipitation (1000$1500 \mathrm{~mm} \mathrm{y}^{-1}$ ) where tropical flammability is highest (Figure S1). Effects of livestock density on shrub cover become stronger with precipitation (Figures 1, S1), as the overall probability of closed canopies increases (Hirota and others 2011; Staal and others 2016).

Significant differences exist among continents in the structure and composition of vegetation. Separate evolutionary histories leading to different functional and architectural traits may explain some of these differences, and how they are shaped by the interplay of climate, soils and disturbances (Lehmann and others 2014). However, the precise mechanisms are still not fully understood. We propose that livestock distribution could partially account for differences in fire frequency and woody vegetation across the tropics. Our remote sensing analyses pave the road for building a holistic picture on the role of livestock in those complex ecological interactions. Only through detailed field observations and experiments will we be able to disentangle which mechanisms drive continental differences.

The openness of South American landscapes has puzzled naturalists and ecologists for centuries (Darwin 1890). These landscapes are found in regions with relatively high precipitation and low fire frequency conditions that generally favor tree establishment. Yet tree cover is low. Our results indicate that high livestock densities in South America play a fundamental role in maintaining these open landscapes. These results agree with findings for southeastern South America (Bernardi and others 2016b). Interestingly, we also find that high livestock density is associated with an increase in fire frequency in the wettest regions. This increase in fire frequency could be explained by grazing management practices in these areas with very high productivity, where grazing alone would be insufficient to maintain open landscapes. Here, rangers use fire as a tool to clear vegetation and prevent regrowth of closed forests (Uhl and Buschbacher 1985; Fearnside 1990; Mistry 1998).

Herbivory is known to reduce fire frequency in large regions of Africa (Archibald and Hempson 2016). At present, livestock is the dominant herbivore, and the distribution of livestock in Africa is similar to the natural herbivore distribution (Archibald and Hempson 2016; Hempson and others 2017). Unlike South America, where livestock densities are high across the precipitation spectrum, 
in wetter regions of Africa, fire is the main consumer of grass biomass and livestock densities are lower (Figure 4). This could be the case in regions with leached, poor-nutrient soils (Hempson and others 2015a). In those regions, recurring fires can maintain tall grasses with low palatability and therefore can impose a dietary constraint especially for mesoherbivores (Waldram and others 2008; Archibald and Hempson 2016). However, intense grazing by, for example, large herds of wildebeest, can overcome this limitation and reduce fire occurrence (McNaughton 1984). A relevant question is whether a potential expansion of livestock into wetter areas in Africa could lead to significant reductions in the occurrence of fire (Venter and others 2017) and to significant changes in ecosystem structure (Bucini and Hanan 2007; Hempson and others 2017; Venter and others 2017).

We observed no significant relationship between livestock and fire below $1000 \mathrm{~mm} \mathrm{y}^{-1}$ for South America and Asia-Australia (Figure S2). This may be explained by lower herbivore densities in these dry regions or be related to the predominance of large widespread fires (Hantson and others 2017) regardless of livestock densities.

In conclusion, our results suggest that in tropical regions where wild large herbivores are no longer dominant, livestock management may shape the structure of savannas and grasslands by maintaining sparse tree cover, reducing fire frequency and favoring the expansion of shrubs and dwarf trees. Therefore, changes in current livestock management regimes can impact fire frequency and may result in structural vegetation changes and woodycover transitions.

\section{ACKNOWLEDGEMENTS}

We thank Matías Arim, Bernardo Flores, Salvador Pueyo and Egbert van Nes for valuable insights. We also thank Stijn Hantson for sharing the fire frequency database. This research was partly supported by grants from the National Research and Innovation Agency (ANII) of Uruguay to RB, the Dutch KNAW to MH, SENSE Research School to AS and the National Natural Science Foundation of China (31770512) to CX. We thank the anonymous reviewers and the editors for the constructive comments.

Data accessibility Data used in this paper can be found in the following databases: Livestock: http://www.fao.org/ag/againfo/resources/en/glw/h ome.html. MODIS tree cover: http://glcf.umd.edu /data/vcf/. Lidar tree height: http://icesat.gsfc.nas a.gov/icesat/glas.php. MODIS fire data: http://mod is-fire.umd.edu/pages/BurnedArea.php.

\section{OPEN ACCESS}

This article is distributed under the terms of the Creative Commons Attribution 4.0 International License (http://creativecommons.org/licenses/by/4 $.0 /$ ), which permits unrestricted use, distribution, and reproduction in any medium, provided you give appropriate credit to the original author(s) and the source, provide a link to the Creative Commons license, and indicate if changes were made.

\section{REFERENCES}

Archibald S, Bond WJ. 2003. Growing tall vs growing wide: tree architecture and allometry of Acacia karroo in forest, savanna, and arid environments. Oikos 102:3-14.

Archibald S, Bond WJ, Stock WD, Fairbanks DHK. 2005. Shaping the landscape: fire-grazer interactions in an African savanna. Ecol Appl 15:96-109.

Archibald S, Hempson GP. 2016. Competing consumers: contrasting the patterns and impacts of fire and mammalian herbivory in Africa. Philos Trans $\mathrm{R}$ Soc Lond Biol Sci 371:20150309.

Archibald S, Roy DP, van Wilgen BW, Scholes RJ. 2009. What limits fire? An examination of drivers of burnt area in Southern Africa. Glob Change Biol 15:613-30.

Asner GP, Elmore AJ, Olander LP, Martin RE, Harris AT. 2004. Grazing systems, ecosystem responses, and global change. Annu Rev Environ Resour 29:261-99.

Asner GP, Levick SR, Kennedy-Bowdoin T, Knapp DE, Emerson R, Jacobson J, Colgan MS, Martin RE. 2009. Large-scale impacts of herbivores on the structural diversity of African savannas. Proc Natl Acad Sci 106:4947-52.

Belsky AJ, Blumenthal DM. 1997. Effects of livestock grazing on stand dynamics and soils in upland forests of the Interior West. Conserv Biol 11:315-27.

Bernardi RE, de Jonge IK, Holmgren M. 2016a. Trees improve forage quality and abundance in South American subtropical grasslands. Agric Ecosyst Environ 232:227-31.

Bernardi RE, Holmgren M, Arim M, Scheffer M. 2016b. Why are forests so scarce in subtropical South America? The shaping roles of climate, fire and livestock. For Ecol Manag 363:21217.

Bond WJ. 2008. What limits trees in C4 grasslands and savannas? Annu Rev Ecol Evol Syst 39:641-59.

Bond WJ, Midgley JJ. 2001. Ecology of sprouting in woody plants: the persistence niche. Trends Ecol Evol 16:45-51.

Bucini G, Hanan NP. 2007. A continental-scale analysis of tree cover in African savannas. Glob Ecol Biogeogr 16:593-605.

Chaturvedi RK, Raghubanshi AS, Singh JS. 2012. Effect of grazing and harvesting on diversity, recruitment and carbon accumulation of juvenile trees in tropical dry forests. For Ecol Manag 284:152-62.

D'Odorico P, Okin GS, Bestelmeyer BT. 2012. A synthetic review of feedbacks and drivers of shrub encroachment in arid grasslands. Ecohydrology 5:520-30. 
Dantas VdL, Hirota M, Oliveira RS, Pausas JG. 2016. Disturbance maintains alternative biome states. Ecol Lett 19:12-19.

Darwin C. 1890. The voyage of the beagle. London: John Murray.

DiMiceli CM, Carroll ML, Sohlberg RA, Hansen MC, Townshend JRG. 2011. Annual global automated MODIS vegetation continuous fields (MOD44B) at $250 \mathrm{~m}$ spatial resolution for data years beginning day 65, 2000-2010. College Park: University of Maryland.

Eldridge DJ, Bowker MA, Maestre FT, Roger E, Reynolds JF, Whitford WG. 2011. Impacts of shrub encroachment on ecosystem structure and functioning: towards a global synthesis. Ecol Lett 14:709-22.

Etchebarne V, Brazeiro A. 2016. Effects of livestock exclusion in forests of Uruguay: soil condition and tree regeneration. For Ecol Manag 362:120-9.

FAO. 1999. Tropical livestock units (TLU). Livestock \& environment toolbox, Rome: FAO.

Fearnside PM. 1990. Fire in the tropical rainforest of the Amazon basin. In: Goldammer JG, Ed. Fire in the tropical biota. Berlin: Springer. p 106-16.

Giglio L, Randerson JT, van der Werf GR. 2013. Analysis of daily, monthly, and annual burned area using the fourth-generation global fire emissions database (GFED4). J Geophys Res Biogeosci 118:317-28.

Griscom HP, Ashton PMS, Berlyn GP. 2005. Seedling survival and growth of native tree species in pastures: implications for dry tropical forest rehabilitation in central Panama. For Ecol Manag 218:306-18.

Hantson S, Scheffer M, Pueyo S, Xu C, Lasslop G, van Nes EH, Holmgren M, Mendelsohn J. 2017. Rare, Intense, Big fires dominate the global tropics under drier conditions. Sci Rep 7:14374.

Hempson GP, Archibald S, Bond WJ. 2015a. A continent-wide assessment of the form and intensity of large mammal herbivory in Africa. Science 350:1056-61.

Hempson GP, Archibald S, Bond WJ. 2017. The consequences of replacing wildlife with livestock in Africa. Sci Rep 7:17196.

Hempson GP, Archibald S, Bond WJ, Ellis RP, Grant CC, Kruger FJ, Kruger LM, Moxley C, Owen-Smith N, Peel MJS, Smit IPJ, Vickers KJ. 2015b. Ecology of grazing lawns in Africa. Biol Rev 90:979-94.

Hirota M, Holmgren M, van Nes EH, Scheffer M. 2011. Global resilience of tropical forest and savanna to critical transitions. Science 334:232-5.

Hoffmann WA, Geiger EL, Gotsch SG, Rossatto DR, Silva LCR, Lau OL, Haridasan M, Franco AC. 2012. Ecological thresholds at the savanna-forest boundary: how plant traits, resources and fire govern the distribution of tropical biomes. Ecol Lett 15:759-68.

Holmgren M. 2002. Exotic herbivores as drivers of plant invasion and switch to ecosystem alternative states. Biol Invasions 4:25-33.

Holmgren M, López BC, Gutiérrez JR, Squeo FA. 2006. Herbivory and plant growth rate determine the success of El Niño Southern Oscillation-driven tree establishment in semiarid South America. Glob Change Biol 12:2263-71.

Holmgren M, Scheffer M. 2017. To tree or not to tree: cultural views from ancient Romans to modern ecologists. Ecosystems 20:62-8.

Huntly N. 1991. Herbivores and the dynamics of communities and ecosystems. Annu Rev Ecol Syst 22:477-503.
Jones P, Harris I. 2013. University of East Anglia Climatic Research Unit, CRU TS3. 21: climatic research unit (CRU) timeseries (TS) version 3.21 of high resolution gridded data of month-by-month variation in climate (Jan. 1901-Dec. 2012). Leeds: NCAS British Atmospheric Data Centre.

Knoop W, Walker B. 1985. Interactions of woody and herbaceous vegetation in a southern African savanna. J Ecol $73: 235-53$.

Lefcheck JS. 2016. piecewiseSEM: piecewise structural equation modelling in $\mathrm{R}$ for ecology, evolution, and systematics. Methods Ecol Evol 7:573-9.

Lehmann CER, Anderson TM, Sankaran M, Higgins SI, Archibald S, Hoffmann WA, Hanan NP, Williams RJ, Fensham RJ, Felfili J, Hutley LB, Ratnam J, San Jose J, Montes R, Franklin D, Russell-Smith J, Ryan CM, Durigan G, Hiernaux P, Haidar R, Bowman DMJS, Bond WJ. 2014. Savanna vegetation-fireclimate relationships differ among continents. Science 343:548-52.

Leonard S, Kirkpatrick J, Marsden-Smedley J. 2010. Variation in the effects of vertebrate grazing on fire potential between grassland structural types. J Appl Ecol 47:876-83.

Los SO, Rosette JAB, Kljun N, North PRJ, Chasmer L, Suárez JC, Hopkinson C, Hill RA, van Gorsel E, Mahoney C, Berni JAJ. 2012. Vegetation height and cover fraction between $60 \mathrm{~S}$ and $60 \mathrm{~N}$ from ICESat GLAS data. Geosci Model Dev 5:413-32.

Markham CG. 1970. Seasonality of precipitation in the United States. Ann Assoc Am Geogr 60:593-7.

McLeod A, Xu C. 2011. bestglm: best subset GLM. R package version 0.33. http://CRAN.R-project.org/package=bestglm. Accessed Mar 2017.

McNaughton SJ. 1984. Grazing lawns: animals in herds, plant form, and coevolution. Am Nat 124:863-86.

Mistry J. 1998. Fire in the cerrado (savannas) of Brazil: an ecological review. Prog Phys Geogr 22:425-48.

Murphy BP, Bowman DM. 2012. What controls the distribution of tropical forest and savanna? Ecol Lett 15:748-58.

Pérez-Harguindeguy N, Díaz S, Garnier E, Lavorel S, Poorter H, Jaureguiberry P, Bret-Harte MS, Cornwell WK, Craine JM, Gurvich DE, Urcelay C, Veneklaas EJ, Reich PB, Poorter L, Wright IJ, Ray P, Enrico L, Pausas JG, de Vos AC, Buchmann N, Funes G, Quétier F, Hodgson JG, Thompson K, Morgan HD, ter Steege H, Sack L, Blonder B, Poschlod P, Vaieretti MV, Conti G, Staver AC, Aquino S, Cornelissen JHC. 2016. Corrigendum to new handbook for standardised measurement of plant functional traits worldwide. Aust J Bot 64:715-6.

Prins HT, van der Jeugd HP. 1993. Herbivore population crashes and woodland structure in East Africa. J Ecol 81:305-14.

Ribeiro PJ Jr, Diggle PJ. 2001. geoR: a package for geostatistical analysis. R News 1:14-18.

Robinson TP, Wint GW, Conchedda G, van Boeckel TP, Ercoli V, Palamara E, Cinardi G, D'Aietti L, Hay SI, Gilbert M. 2014. Mapping the global distribution of livestock. PloS ONE 9:e96084

Roques K, O'Connor T, Watkinson A. 2001. Dynamics of shrub encroachment in an African savanna: relative influences of fire, herbivory, rainfall and density dependence. J Appl Ecol $38: 268-80$.

Roy DP, Boschetti L, Justice CO, Ju J. 2008. The collection 5 MODIS burned area product—global evaluation by comparison with the MODIS active fire product. Remote Sens Environ 112:3690-707. 
Scheffer M, Bascompte J, Brock WA, Brovkin V, Carpenter SR, Dakos V, Held H, van Nes EH, Rietkerk M, Sugihara G. 2009. Early-warning signals for critical transitions. Nature 461:53-9.

Scheffer M, van Nes EH, Holmgren M, Hughes T. 2008. Pulsedriven loss of top-down control: the critical-rate hypothesis. Ecosystems 11:226-37.

Scheffer M, Vergnon R, Cornelissen JHC, Hantson S, Holmgren M, van Nes EH, Xu C. 2014. Why trees and shrubs but rarely trubs? Trends Ecol Evol 29:433-4.

Scholes RJ, Archer SR. 1997. Tree-grass interactions in savannas. Annu Rev Ecol Syst 28:517-44.

Shipley LA. 1999. Grazers and browsers: how digestive morphology affects diet selection. Grazing Behav Livest Wildl 70:20-7.

Staal A, Dekker SC, Xu C, van Nes EH. 2016. Bistability, spatial interaction, and the distribution of tropical forests and savannas. Ecosystems 19:1080-91.

Staal A, van Nes EH, Hantson S, Holmgren M, Dekker SC, Pueyo S, Xu C, Scheffer M. 2018. Resilience of tropical tree cover: the roles of climate, fire, and herbivory. Glob Change Biol 24:5096-109.

Staver AC, Archibald S, Levin SA. 2011. The global extent and determinants of savanna and forest as alternative biome states. Science 334:230-2.

Staver AC, Bond WJ. 2014. Is there a 'browse trap'? Dynamics of herbivore impacts on trees and grasses in an African savanna. J Ecol 102:595-602.

Stevens N, Lehmann CER, Murphy BP, Durigan G. 2017. Savanna woody encroachment is widespread across three continents. Glob Change Biol 23:235-44.

Suding KN, Gross KL, Houseman GR. 2004. Alternative states and positive feedbacks in restoration ecology. Trends Ecol Evol 19:46-53.
Thornton PK, Herrero M. 2010. Potential for reduced methane and carbon dioxide emissions from livestock and pasture management in the tropics. Proc Natl Acad Sci 107:19667-72.

Uhl C, Buschbacher R. 1985. A disturbing synergism between cattle ranch burning practices and selective tree harvesting in the Eastern Amazon. Biotropica 17:265-8.

van Langevelde F, van De Vijver CA, Kumar L, van De Koppel J, De Ridder N, van Andel J, Skidmore AK, Hearne JW, Stroosnijder L, Bond WJ. 2003. Effects of fire and herbivory on the stability of savanna ecosystems. Ecology 84:337-50.

van Nes EH, Scheffer M. 2005. A strategy to improve the contribution of complex simulation models to ecological theory. Ecol Model 185:153-64.

van Nes EH, Staal A, Hantson S, Holmgren M, Pueyo S, Bernardi RE, Flores BM, Xu C, Scheffer M. 2018. Fire forbids fifty-fifty forest. PLoS One 13:e0191027.

Venter ZS, Hawkins H-J, Cramer MD. 2017. Implications of historical interactions between herbivory and fire for rangeland management in African savannas. Ecosphere 8:e01946.

Waldram MS, Bond WJ, Stock WD. 2008. Ecological engineering by a mega-grazer: white rhino impacts on a South African Savanna. Ecosystems 11:101-12.

Walter H. 1939. Grassland, savanne und busch der arideren teile Afrikas in ihrer okologischen bedingheit. Jahrbucher für Wissenschaftliche Botanik 87:750-860.

Xu C, Hantson S, Holmgren M, van Nes EH, Staal A, Scheffer M. 2016. Remotely sensed canopy height reveals three pantropical ecosystem states. Ecology 97:2518-21.

Xu C, Staal A, Hantson S, Holmgren M, van Nes EH, Scheffer M. 2018. Remotely sensed canopy height reveals three pantropical ecosystem states: reply. Ecology 99:235-7. 